\title{
Assessment of Factors Influencing Production, Consumption and Utilization of Indigenous Vegetables in Kabuoch Location, Homa Bay County
}

\author{
Shaida Adera ${ }^{1}$, Nyamwamu Charles ${ }^{2, a^{*}}$, Mwamburi Lizzy ${ }^{3, b}$ \\ ${ }^{1}$ Department of Biological Sciences, University of Eldoret, P. O. Box 3900-30100, Eldoret, Kenya. \\ ${ }^{2}$ Department of Agriculture, Mawego Technical Training Institute, P. O. Box 269, Oyugis, Kenya. \\ ${ }^{3}$ Department of Biological Sciences, University of Eldoret, P. O. Box 1125-30100, Eldoret, Kenya. \\ aE-mail: nyamwamucharles@gmail.com; Cell phone: +254725566033. \\ bE-mail: lizzymwamburi@hotmail.com; Cell phone: +254729205412
}

${ }^{*}$ Corresponding author

Keywords: Indigenous vegetables, Biodiversity, Utilization, Amaranthus, Kabuoch

\begin{abstract}
Indigenous vegetables are important sources of both macro and micronutrients which are important for a healthy body. In addition, they also play a role in food security because most are fast maturing therefore being a valuable source of vitamins all the year round and are mostly used as an accompaniment with a staple cereals-based diet such as ugali. Therefore, they encourage the consumption and cultivation of indigenous leafy vegetables. This study sought to carry out an assessment of indigenous vegetables produced, utilization and factors influencing their production and consumption among residents of Kabuoch location, Homa bay County. A household survey was carried out to collect primary data. Five administrative sub-locations were randomly sampled for the study. Twenty households were purposively sampled from each sub-location to make a sample size of 120 households. Questionnaires were used in data collection. The questionnaire contained both open ended and closed ended questions. Questionnaires were administered to 120 households to collect data on production, knowledge on utilization of indigenous vegetables and factors influencing their cultivation. Data collected was subjected to both descriptive and inferential analysis. Only 10 indigenous vegetables were found to be cultivated. Black night shade (Solanum nigrum) and Cowpea leaves (Vigna unguiculata) being greatly preferred by most households. However, most households regarded indigenous vegetables as food meant expectant and lactating mothers. Attitude and wrong perceptions were found to be primary factors influencing production and consumption of indigenous vegetables in Kabuoch location, Homa bay County. There is need to create awareness on the value of indigenous vegetables, intensification of conservation and introduction of more indigenous vegetables to the community in order to enhance food security.
\end{abstract}

\subsection{Introduction}

Vegetables can be categorized as either exotic or indigenous types. Exotic vegetables in Kenya are those that have recently been introduced and they include cabbages, carrots and spinach. Indigenous vegetables are the traditional vegetable species that are locally important for the sustainability of economies, human nourishment, health, and social systems [12]. Additionally, indigenous vegetables can either be those that were originally in an area [1] or introduced and have been used over a long period of time until they have formed part of the culture and tradition of a community [16]. Indigenous vegetables such as nightshade (Solanum species), spider plant (Cleome species), amaranth (Amaranthus species), cowpea (Vigna species), sweet potato leaves (lpomeas species), pumpkin leaves (Cucurbita species), jute mallow (Corchorus olitorius) and cassava leaves (Manihot esculenta) among others [14].

Indigenous vegetables have yet to attain global recognition to the same extent as major vegetable commodities such as tomato or cabbage as observed by [1]. Generally, though majority of the indigenous vegetables are utilized globally, their collective value to human beings is greatly 
significant. According to [4], these vegetable plants need great attention and venture in agronomic farming and development than they are accorded presently. Indigenous vegetables are core plants for greater utilization of crop biodiversity in horticulture since they are already consumed and enjoyed locally and can be produced profitably in both rural and urban environments [2].

Vegetable production and consumption has been seen to bring about nutritional and economic improvements especially if the production is for income generation [13]. Indigenous vegetables are increasingly getting popular for their contribution in food security to millions of Africans in rural and urban areas [14]. Indigenous vegetables have been regarded as a poor man's diet 'and therefore some people shied away from their consumption. However, this perception is fading away since a larger human population have begun to consume them for their nutritional and medicinal properties [22]. For instance, black night shade (Gynandropsis gynandra) is sold in supermarkets, an indication that these vegetables are no longer associated with the poor [21].

Indigenous leafy vegetables are grown for their high nutritive value, several health benefits, agronomic advantages and also generation of income. Despite these benefits, indigenous vegetables are faced with challenges of marketing whereby their marketing system is still informal with economic inefficiencies, neglect and stigmatization, on availability of high quality seed and planting material, adequate awareness of value and potential of indigenous vegetables, inadequate research [21]. With the current modernization trend, there is a reduction in the consumption of these indigenous vegetables since people have shifted their attention to other vegetables and foods that are easy to prepare. There has also been a change in taste preference since younger generations prefer sweetened, fatty fat foods as observed by [7]. In addition, these vegetables are also being replaced with other foods such as meat, milk and other processed foods that do not contain the important micronutrients found in indigenous leafy vegetables.

The use of African indigenous leafy vegetables serve as immune boosters to human health, however, the available literature indicates that there is vitamin deficiency among people especially the youth, women and people's over reliance to other purchased foods that are less nutritious and poverty levels compounds the people's ignorance on value of indigenous vegetables to human health [7]. The purpose of this research was therefore to contribute to scientific basis for the utilization of indigenous vegetables in Kenya for evidence based promotion and improvement of production as well as consumption of the indigenous vegetables.

\subsection{Materials and Methods}

\subsection{Research Design}

A household survey was carried out in Kabuoch location, Homa bay County.

\subsection{Description of the Study Area}

Kabuoch location is situated $24 \mathrm{~km}$ from Homa bay town. The location is subdivided into wards. It is located along the North Eastern part of Lake Victoria. In the North West, a boundary is formed inside the lake in the East by Kochia / Kanyada boundary, in the west by Kanyada Kanyamwa location boundaries and in the south by the line between Kabunde airstrip and turban passing through Ogande Girls secondary school. Kabuoch location is further divided into North and South Kabuoch covers total area of $237.0 \mathrm{~km}^{2}$ and a population of 61602 inhabitants, based on population census of 2019. Over $77 \%$ of this population is living below the poverty line [8].

It lies at an altitude of approximately 4000 feet at 1330 meters above sea level. Its climate condition is semi-arid and it has two rainy seasons. Long rains which falls between the months of March and May while short rains fall between September and November with approximately measurements of 1180 Milliliters. Its daily temperature range is between $26^{0}-28^{\circ} \mathrm{C}$. Fishing is the main economic activity in the area. 


\subsection{Sample Size Sampling Procedures}

From the nine sub locations, six of them were randomly sampled for the study with the assistance of the Ministry of Agriculture extension officers. The sampling unit was individual households. From each of the sampled sub-locations, 20 households were purposively sampled to make a sample size of 120 households for the study.

Table 2.1 Administrative units in Kabuoch Location

\begin{tabular}{l|l}
\hline Location & Sub-locations \\
\hline Kabuoch North & Kawuor \\
& Karading \\
& Konyango \\
& West Kachieng, \\
& East Kachieng \\
& Konyango-Kachwanya \\
& Koguta \\
Kabuoch South & Kobita \\
\hline
\end{tabular}

Source; County Development Plan; Homa bay County, 2020

\subsection{Data Collection Procedure}

Questionnaires were used in data collection. A structured pretested questionnaire was used to carry out a household survey was carried out targeting collection of primary data. The questionnaires contained both open ended and closed ended questions. Questionnaires were administered to the respondents in order to collect data on cultivation, utilization and factors influencing indigenous vegetable production and their perceptions on indigenous vegetables (Appendix 1). Photographs capturing the various indigenous vegetables cultivated and their utilization were also taken.

\subsection{Data Analysis}

Data collected was subjected to both descriptive and inferential analysis (one-Sample t-test) and presented using tables and figures.

\subsection{Results}

\subsection{Indigenous Vegetables Produced in Kabuoch location, Homa bay County}

Ten different indigenous vegetables were identified and their common names, botanical names and local names recorded as shown in Table 3.1.

Table 3.1 Indigenous Vegetables Produced in Kabuoch location, Homa bay County

\begin{tabular}{l|l|l|l}
\hline No. & Common Name & Botanical Name & Local Name \\
\hline 1 & Black night shade & Solanum nigrum & Managu \\
2 & Spider plant leaves & Gynandropsis gynandra & Akeyo \\
3 & Pumpkin leaves & Curcubita spp & Susa \\
4 & Pig weed & Amaranthus hybridus & Ododo \\
5 & Jute leaves & Corchorus olitorius & Mrenda \\
6 & Bean leaves & Phaseolus vulgaris & Kuneni \\
7 & Common nettle & Urtica dioca & Aila \\
8 & Indian Spinach & Basella alba & Nderema \\
9 & Kale leaves & Brassica oleraceae & Sukuma wiki \\
10 & Cowpea leaves & Vigna unguiculata & Boo \\
\hline
\end{tabular}




\subsubsection{Households Producing Indigenous vegetables in Kabuoch location, Homa bay County}

The frequency of households producing indigenous vegetables in Kabuoch location, Homa bay County was computed. Kales (Brassica oleraceae) had the highest frequency $25(20.8 \%)$ of the households under cultivation followed by Black night shade (Solanum nigrum) 18 (15.0\%) while the least indigenous vegetable cultivated was common neetle (Urtica dioca) with a frequency of 5 (4.2\%) as indicated in Table 3.2.

Table 3.2 Frequency of households producing indigenous vegetables in Kabuoch location, Homa bay County

\begin{tabular}{|c|c|c|c|c|c|}
\hline No. & Common Name & Botanical Name & Local Name & $\begin{array}{l}\text { Frequency } \\
\text { households } \\
\text { (f) }\end{array}$ & $\begin{array}{l}\text { Percentage } \\
\text { of } \\
\text { households } \\
(\%)\end{array}$ \\
\hline 1 & Black night shade & Solanum nigrum & Managu & 18 & 15.0 \\
\hline 2 & Spider plant leaves & Gynandropsis gynandra & Akeyo & 14 & 12.5 \\
\hline 3 & Pumpkin leaves & Curcubita spp & Susa & 6 & 5.0 \\
\hline 4 & Pig weed & Amaranthus hybridus & Ododo & 10 & 8.0 \\
\hline 5 & Jute leaves & Corchorus olitorius & Mrenda & 6 & 5.0 \\
\hline 6 & Bean leaves & Phaseolus vulgaris & Kuneni & 11 & 9.1 \\
\hline 7 & Common nettle & Urtica dioca & Aila & 5 & 4.2 \\
\hline 8 & Indian Spinach & Basella alba & Nderema & 10 & 8.3 \\
\hline 9 & Kale leaves & Brassica oleraceae & Sukuma wiki & 25 & 20.8 \\
\hline 10 & Cowpea leaves & Vigna unguiculata & Boo & 15 & 12.5 \\
\hline & \multicolumn{3}{|l|}{ TOTALS } & 120 & 100 \\
\hline
\end{tabular}

3.2 Indigenous Knowledge on Utilization of Indigenous Vegetables among residents of Kabuoch location, Homa Bay County

Indigenous knowledge on utilization of indigenous vegetables from the respondents was established. Nine reasons for indigenous vegetable utilization were recorded. Vegetables are meant for expectant mothers scored the highest frequency $27(22.5 \%)$ followed closely by indigenous vegetables' medicinal properties for recuperating patients with $20(16.7 \%)$. Stimulates male power had a frequency of $15(12.5 \%)$, source of strength for the aged, $14(11.5 \%)$, boosts immunity, 12 $(10.0 \%)$, general source of energy for the body, $10(8.3 \%)$ while as an important dish for special occasions, treatment of eye infections or stomachaches and used as livestock feed had frequencies of $9(7.5 \%), 8(6.2 \%)$ and $5(4.2 \%)$ respectively as illustrated in Table 3.3. 
Table 3.3 Indigenous Knowledge on Utilization of indigenous vegetables in Kabuoch location, Homa bay County

\begin{tabular}{|c|c|c|c|}
\hline No. & $\begin{array}{l}\text { Knowledge on Utilization of } \\
\text { indigenous vegetables }\end{array}$ & $\begin{array}{l}\text { Frequency } \\
\text { households (f) }\end{array}$ & $\begin{array}{l}\text { Percentage } \\
\text { households (\%) }\end{array}$ \\
\hline 1 & $\begin{array}{l}\text { Important dish for special occasions } \\
\text { Source of strength for the aged }\end{array}$ & 9 & 7.5 \\
\hline 2 & General source of energy for the body & 14 & 11.5 \\
\hline 3 & $\begin{array}{l}\text { Treatment for eye infections and } \\
\text { stomachaches }\end{array}$ & 10 & 8.3 \\
\hline 4 & $\begin{array}{l}\text { Stimulation of male potency } \\
\text { Used as animal feed }\end{array}$ & 8 & 6.2 \\
\hline 5 & Dish for expectant and lactating mothers & 15 & 12.5 \\
\hline 6 & Boost for body immunity & 5 & 4.2 \\
\hline 7 & $\begin{array}{l}\text { Medicinal properties for recuperating } \\
\text { patients }\end{array}$ & 27 & 22.5 \\
\hline 8 & & 12 & 10.0 \\
\hline 9 & & 20 & 16.7 \\
\hline & TOTALS & 120 & 100 \\
\hline
\end{tabular}

There was a statistical significance $(\mathrm{p}<0.05)$ on indigenous knowledge on utilization of indigenous vegetables in Kabuoch location, Homa bay County as illustrated in Table 3.4.

Table 3.4 Data Analysis Output on Indigenous Knowledge on Utilization of indigenous vegetables in Kabuoch location, Homa bay County

One-Sample Test

\begin{tabular}{|c|c|c|c|c|c|c|}
\hline & \multicolumn{6}{|c|}{ Test Value } \\
\hline & \multirow[t]{2}{*}{$\mathrm{t}$} & \multirow[t]{2}{*}{$\mathrm{df}$} & \multirow[t]{2}{*}{$\begin{array}{c}\text { Sig. } \\
\text { (2-tailed) }\end{array}$} & \multirow[t]{2}{*}{$\begin{array}{c}\text { Mean } \\
\text { Difference }\end{array}$} & \multicolumn{2}{|c|}{$\begin{array}{l}95 \% \text { Confidence Interval of } \\
\text { the Difference }\end{array}$} \\
\hline & & & & & Lower & Upper \\
\hline freq & 1.017 & 9 & .0336 & 2.00000 & -2.4483 & 6.4483 \\
\hline & & & & & & \\
\hline
\end{tabular}

3.3 Household Preference Ranking of Indigenous Vegetables in Kabuoch location, Homa bay County

Black night shade (Solanum nigrum) was most preferred and ranked first with frequency of 24 (20.0\%) and was followed by Cowpeas (Vigna unguiculata) with frequency of $17(14.2 \%)$. In the third rank was Pumpkin leaves (Curcubita spp), 15 (12.5\%), followed by Spider plant leaves (Gynandropsis gynandra) 13 (10.8\%) while Jute leaves (Corchorus olitorius) was ranked fifth with frequency of $10(8.3 \%)$. Indian Spinach (Basella alba) was ranked sixth with frequency of $11(9.2 \%)$ while Bean leaves (Phaseolus Vulgaris) was ranked seventh with frequency of 10 (8.3\%). The Pig weed (Amaranthus hybridus) was ranked eight with frequency of 9 (7.6\%), Kale leaves (Brassica oleraceae) ranked ninenth with frequency of 7 (5.8\%) while Common nettle (Urtica dioca) was ranked least with frequency of $4(3.3 \%)$ as shown in Table 3.5 . 
Table 3.5 Households Preference Ranking of Indigenous Vegetables in Kabuoch location, Homa

\begin{tabular}{l|l|l|l|l}
\hline Vegetable Crop & $\begin{array}{l}\text { Local } \\
\text { Name }\end{array}$ & Rank & $\begin{array}{l}\text { Frequency of } \\
\text { households (f) }\end{array}$ & $\begin{array}{l}\text { Percentage of } \\
\text { households (\%) }\end{array}$ \\
\hline $\begin{array}{l}\text { Black night shade } \\
\text { (Solanum nigrum) } \\
\begin{array}{l}\text { Cowpea leaves } \\
\text { (Vigna unguiculata) }\end{array}\end{array}$ & Managu & 1 & 24 & 20.0 \\
$\begin{array}{l}\text { Pumpkin leaves } \\
\text { (Curcubita spp) }\end{array}$ & Boo & 2 & 17 & 14.2 \\
$\begin{array}{l}\text { Spider plant leaves } \\
\text { (Gynandropsis gynandra) }\end{array}$ & Akeyo & 4 & 13 & 12.5 \\
$\begin{array}{l}\text { Jute leaves } \\
\text { (Corchorus olitorius) } \\
\begin{array}{l}\text { Indian Spinach } \\
\text { (Basella alba) }\end{array}\end{array}$ & Mrenda \\
$\begin{array}{l}\text { Bean leaves (Phaseolus } \\
\text { Vulgaris) }\end{array}$ \\
$\begin{array}{l}\text { Pig weed (Amaranthus } \\
\text { hybridus) } \\
\text { Kale leaves } \\
\text { (Brassica oleraceae) } \\
\text { Common nettle (Urtica } \\
\text { dioca) }\end{array}$
\end{tabular}

The percentages of households preference ranking of indigenous vegetables in Kabuoch location, Homa bay County was presented as illustrated in Figure 3.1.

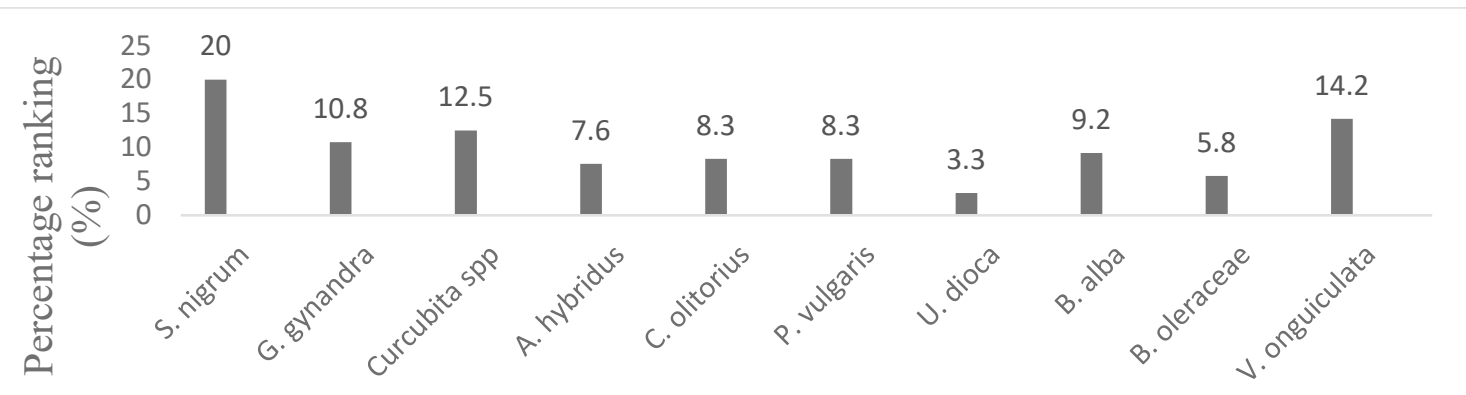

Indigenous vegetables

Figure 3.1 Percentages of households preference ranking on indigenous vegetables in Kabuoch location, Homa bay County

There was a statistical significance $(\mathrm{p}<0.05)$ on households preference ranking of indigenous vegetables in Kabuoch location, Homa bay County as indicated in Table 3.6. 
Table 3.6 Statistical Analysis on Households Preference Ranking of Indigenous Vegetables in Kabuoch location, Homa bay County

One-Sample Test

\begin{tabular}{|c|c|c|c|c|c|}
\hline \multicolumn{6}{|c|}{ Test Value $=0$} \\
\hline \multirow[t]{2}{*}{$\mathrm{t}$} & \multirow[t]{2}{*}{ df } & \multirow[t]{2}{*}{$\begin{array}{l}\text { Sig. (2- } \\
\text { tailed) }\end{array}$} & \multirow[t]{2}{*}{$\begin{array}{c}\text { Mean } \\
\text { Difference }\end{array}$} & \multicolumn{2}{|c|}{$\begin{array}{l}95 \% \text { Confidence Interval of the } \\
\text { Difference }\end{array}$} \\
\hline & & & & Lower & Upper \\
\hline 6.897 & 9 & .010 & 12.20000 & 8.1985 & 16.2015 \\
\hline 5.745 & 9 & .010 & 5.50000 & 3.3341 & 7.6659 \\
\hline
\end{tabular}

3.4 Factors Influencing Production and Consumption of Indigenous Vegetables among residents of Kabuoch Location, Homa Bay County

Twenty six $(21.7 \%)$ of the respondents indicated that attitude influenced their production and consumption of indigenous vegetables followed by $22(18.3 \%)$ of the respondents who indicated that wrong perception on indigenous vegetables influenced their consumption. Personal tastes/preferences had 18 (15.0\%), Knowledge on nutritional value of indigenous vegetables had $16(13.3 \%)$ while climatic conditions, limited land, market dynamics and change of diet had $13(10.8 \%), 11(9.2 \%), 8$ $(6.7 \%)$ and $6(5.0 \%)$ respectively as shown in Table 3.7.

Table 3.7 Factors Influencing Production and Consumption of Indigenous Vegetables among residents of Kabuoch Location, Homa Bay County

\begin{tabular}{l|l|l|l}
\hline No. & \multicolumn{1}{|c|}{ Factor } & $\begin{array}{l}\text { Frequency of } \\
\text { households (f) }\end{array}$ & $\begin{array}{l}\text { Percentage of } \\
\text { households (\%) }\end{array}$ \\
\hline 1 & $\begin{array}{l}\text { Knowledge on nutritional } \\
\text { value of the indigenous }\end{array}$ & 16 & 13.3 \\
& vegetables & & \\
2 & Limited Land & 11 & 9.2 \\
3 & Change of diet & 8 & 5.0 \\
4 & Market dynamics & 22 & 6.7 \\
5 & Wrong perceptions & 13 & 18.3 \\
6 & Climatic conditions & 26 & 10.8 \\
7 & Attitude & 18 & 21.7 \\
8 & Tastes/preferences & $\mathbf{1 2 0}$ & 15.0 \\
\hline \multicolumn{2}{l}{ TOTALS } & $\mathbf{1 0 0}$ \\
\hline
\end{tabular}

However, there was no statistical significance $(\mathrm{p}>0.05)$ on factors influencing production and consumption of indigenous vegetables among residents of Kabuoch Location, Homa Bay County as shown in Table 3.8 .

Table 3.8 Statistical Analysis on Factors Influencing Production and Consumption of Indigenous Vegetables among residents of Kabuoch Location, Homa Bay County

One-Sample Test

\begin{tabular}{|c|c|r|r|r|r|c|}
\hline & \multicolumn{6}{|c|}{ Test Value $=0$} \\
\cline { 2 - 5 } & $\mathrm{t}$ & $\mathrm{df}$ & $\begin{array}{c}\text { Sig. (2- } \\
\text { tailed) }\end{array}$ & $\begin{array}{c}\text { Mean } \\
\text { Difference }\end{array}$ & $\begin{array}{c}95 \% \text { Confidence Interval of } \\
\text { the Difference }\end{array}$ \\
\cline { 5 - 7 } & & & & & Lower & Upper \\
\hline Frequency & 6.179 & & .000 & 15.00000 & 9.2598 & 20.7402 \\
\hline
\end{tabular}




\subsection{Discussions}

\subsection{Households Cultivating Indigenous vegetables in Kabuoch location, Homa bay County}

The study found out that there were relatively fewer number of households cultivating indigenous vegetables and implying that the value of indigenous vegetables had not yet been embraced. These findings were in agreement with those obtained by [22] who observed that modernization had resulted in replacement of indigenous vegetables with other foods such as meat, milk and other processed foods that did not possess the important micronutrients found in indigenous leafy vegetables. The author further noted that factors such as change of diet, tastes and wrong perceptions are among several other factors that have reduced the cultivation of indigenous leafy vegetables in many rural areas.

\subsection{Indigenous Knowledge on Utilization of Indigenous Vegetables among residents of Kabuoch location, Homa Bay County}

Results of the current study revealed that individuals of various households had different knowledge on utilization of indigenous vegetables. At household level, indigenous vegetables were utilized differently depending on the importance leveled on a particular indigenous vegetable. These findings were also supported by [24] who observed that sufficiency in indigenous knowledge among individuals enhances level of utilization of indigenous vegetables among rural inhabitants. [2] also reported similar results, when he observed that the demand for fluted pumpkin and English spinach were high only among elderly consumers in Nigeria. In line with these findings, [22] noted that in India, indigenous vegetables were utilized by a small part of the population since they contained oxidant compounds for protecting and healing malnutrition-related diseases.

Indigenous vegetables have been proven to enhance eye sight and improve maternal health. In support of these findings, [15] observed that indigenous vegetables play an important part in human health since they are known to reduce vitamin A and iron deficiency in vulnerable groups such as elderly people and pregnant women, and in improving maternal health and the health of children under five years old. The current study also revealed that indigenous vegetables were utilized in boosting of male potency, In support of these findings, [20] also emphasizes the role of traditional vegetables in the management of HIV/AIDS, and in promotion of male potency and provision of energy to the body.

\subsection{Household Preference Ranking of Indigenous Vegetables in Kabuoch location, Homa bay County}

Different households had diverse preference on utilization of various indigenous vegetables. In a related study, [6] observed that the bitter taste in slender leaf constrained its acceptance for consumption in most households. Additionally, in support of these study findings, [7] revealed that some indigenous vegetables like the common nettle (Urtica dioca) was less likely to be accepted for utilization by literate urban inhabitants.

\subsection{Factors Influencing Production and Consumption of Indigenous Vegetables among residents of Kabuoch Location, Homa Bay County}

Our study found that production and consumption of indigenous vegetables in Kabuoch, Homa bay County was influenced by various factors. Market dynamics influenced production and consumption of indigenous vegetables among households. These results are in agreement with those obtained by [23] who found out that distant market outlets were constrain to consumer access to household goods. In support of these findings, [17] and [6] observed that consumers are less willing to shop for indigenous vegetables from distant markets that involved time in traveling. Although climatic conditions were observed to be a factor that influenced production and consumption of indigenous vegetables, [9] disagreed indicating that indigenous vegetables showed substantive biodiversity that were adapted to specific marginal soils and climatic conditions that could be grown with minimal external inputs. 
Wrong perception towards indigenous vegetables influenced their production and consumption. In support of these findings, [19] observed that consumers in Nairobi had a negative perception about African leafy vegetables as they are considered "low status" food. This view was also held in the South and Central Pacific regarding local indigenous vegetables. However, [13, 19] study also showed that consumers could easily adopt positive perceptions after being exposed to simple media messages on the value of African leafy vegetables for health and nutrition.

Limited land due to increased settlement of human population and high demand for staple food crops has reduced intensity of cultivation and consumption of indigenous vegetables. In line with these findings, $[11,12]$ noted that indigenous vegetable production in all cropping systems and in home gardens was under constant threat from overexploitation of land for commercial or subsistence reasons and rapid urbanization.

The study revealed that attitude also influenced production and consumption of indigenous vegetables in Kabuoch location, Homa bay County. In tandem with these findings, $[5,10,18]$ found out that wealthier people and urbanized dwellers perceived indigenous vegetables as food meant for "poor-rural man". The study noted that possession of indigenous knowledge and preferences on particular indigenous vegetables influenced their consumption in Kabuoch location, Homa bay County. Similar findings were obtained by [7] who observed that being familiar with the importance of consuming specific indigenous vegetables influences their consumption and enhances its preference.

\subsection{Conclusion}

There was a small number of indigenous vegetables cultivated in Kabuoch location, Homa bay County. Further, the study revealed that the community possessed some indigenous knowledge on indigenous vegetable utilization in terms of the different uses of the indigenous vegetable particularly on human nutrition and health that has not yet been documented and/or authenticated. Household preference on particular indigenous vegetables influenced production and consumption of some indigenous vegetables. Various factors such as attitude, households tastes, limited land, wrong perception and climatic conditions among others influenced production and consumption of indigenous vegetables in Kabuoch location, Homa bay County.

\section{Recommendations}

There is a need for intensification of agronomic research on nutritional value of indigenous vegetables and dissemination of the knowledge to households. This will aid in widening household understanding of plant husbandry and thus improve indigenous vegetables production.

There is also a need for conservation and introduction of more these indigenous vegetables to the community. The ministry of Agriculture should conduct promotional campaigns on the importance of embracing indigenous vegetables on human diet. Additionally, communities should be advised to source and plant indigenous vegetables adapted to their respective ecological regions.

\section{Conflict of Interest}

"The author(s) declare(s) that there is no conflict of interest."

There was no role of the funding sponsors in the design of the study; in the collection, analyses or interpretation of data; in the writing of the manuscript, or in the decision to publish the results.

\section{Acknowledgement}

The author would like to acknowledge the input, support and guidance accorded by all the farm managers and management staff of the surveyed farms, the survey biometricians and Agricultural extension officers at the sub county level, Kabuoch. 


\section{Appendices}

\section{Appendix 1: Household Questionnaire}

\section{Department of Biological Sciences}

I am a student at University of Eldoret and wishes to request for your participation in a study I am doing entitled, "Assessment of indigenous vegetables cultivated, utilization and factors influencing their cultivation and consumption among residents of Kabuoch Location, Homa Bay County." The study will not take you long to complete and your personal information will not be disclosed to anyone other than the researcher involved in this study.

The information provided here will be treated with utmost confidentiality and in no cases will the responses from the individual respondents be identified. Instead, the data will be pooled in aggregate form only. There will be no direct benefit other than the sense of helping the public at large in contributing to the knowledge established.

I kindly ask for your assistance in filling in the questionnaire as truthfully as possible.

\section{PART 1: Informants' consent for the participation in the study}

I hereby give my full consent and conscious to participate in this study and declare that to the best of my knowledge the information that I have provided are true, accurate and complete.

Date....

Signature

\section{PART 2: Data}

\section{Indigenous Vegetables Cultivated in Kabuoch location, Homa bay County}

1. What are the examples of indigenous vegetables you cultivate on your farm?

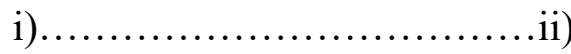

iv).

.v)

Indigenous Knowledge on Utilization of Indigenous Vegetables among residents of Kabuoch location, Homa Bay County

2. Below are various statements on knowledge of utilization of Indigenous vegetables. Tick $(\sqrt{ })$ your right opinion against each statement.

\begin{tabular}{|l|l|l|}
\hline No. & $\begin{array}{l}\text { Knowledge on Utilization of } \\
\text { indigenous vegetables }\end{array}$ & Tick $(\sqrt{ })$ \\
\hline 1 & $\begin{array}{l}\text { Important dish for special } \\
\text { occasions }\end{array}$ & \\
\hline 2 & Source of strength for the aged & \\
\hline 3 & $\begin{array}{l}\text { General source of energy for the } \\
\text { body }\end{array}$ & \\
\hline 4 & $\begin{array}{l}\text { Treatment for eye infections } \\
\text { and stomachaches }\end{array}$ & \\
\hline 5 & Stimulation of male potency & \\
\hline 6 & Used as animal feed & \\
\hline 7 & $\begin{array}{l}\text { Dish for expectant and lactating } \\
\text { mothers }\end{array}$ & \\
\hline 8 & Boost for body immunity & $\begin{array}{l}\text { Medicinal properties for } \\
\text { recuperating patients }\end{array}$ \\
\hline 9 &
\end{tabular}


Households Preference Ranking of Indigenous Vegetables in Kabuoch location, Homa bay County

3) Rank the indigenous vegetables you cultivate based on preference (assign them values from number 1-10 so that the most preferred has the value of 1 while the least preferred has the value of 10 .

\begin{tabular}{|l|l|}
\hline Indigenous Vegetable & Rank \\
\hline & \\
\hline & \\
\hline & \\
\hline & \\
\hline & \\
\hline & \\
\hline & \\
\hline & \\
\hline & \\
\hline
\end{tabular}

Factors Influencing Cultivation and Consumption of Indigenous Vegetables among residents of Kabuoch Location, Homa Bay County

4) What challenges do you face as a vegetable farmer in production and consumption of indigenous vegetables?

i).

iv).

ii)

$. v)$.

Thank you for your cooperation

Thanks

Appendix 2: Photographs of Cultivated indigenous vegetables in Kabuoch, Homa bay County

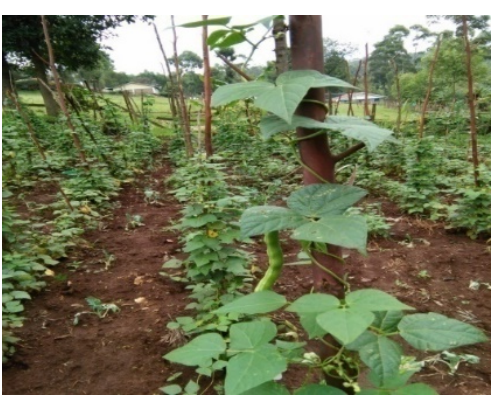

Common name: Common beans Botanical name: Phaseolus vulgaris

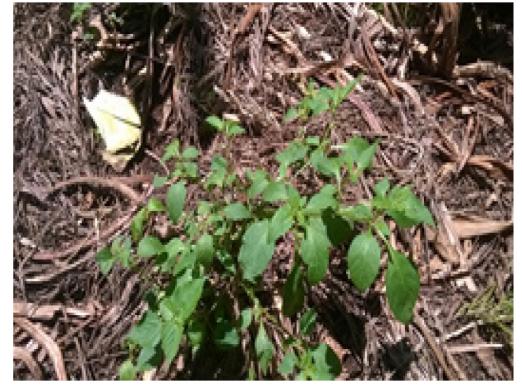

Common name: Black night shade

Botanical name: Solanum nigrum 


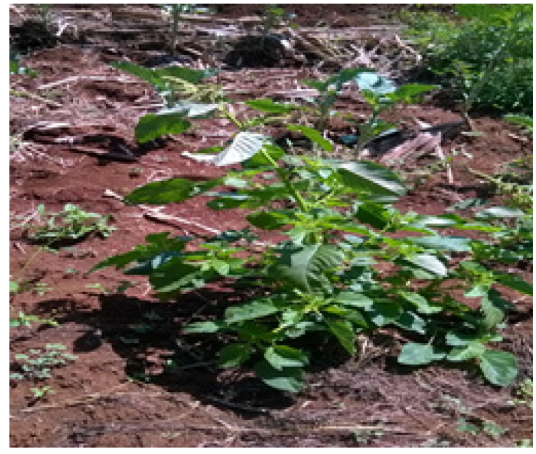

Common name: Pig weed Botanical name: Amaranthus hybridus

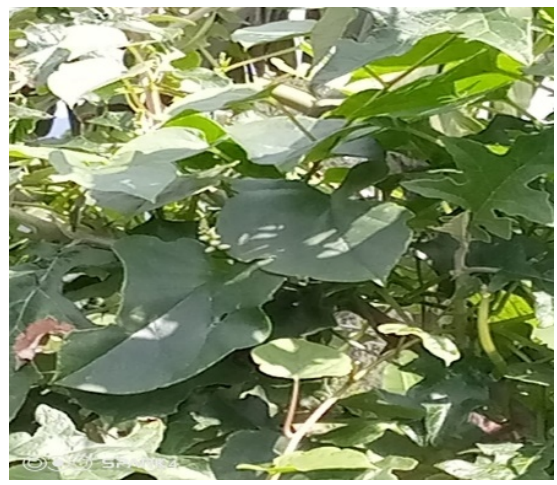

Common name: Indian spinach Botanical name: Basella alba

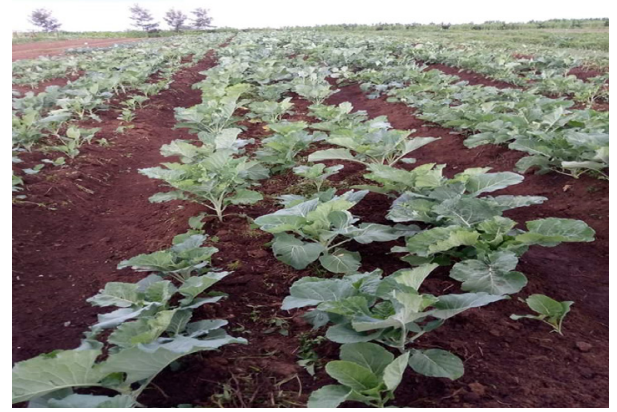

Common name: Kales

Botanical name: Brassica oleraceae

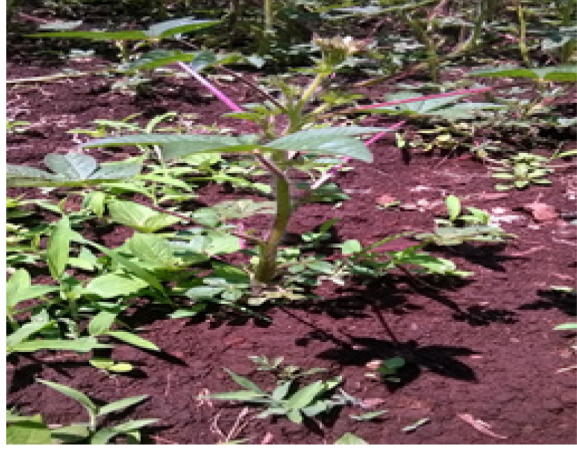

English name: Spider plant Botanical name: Gynandropsis gynandra

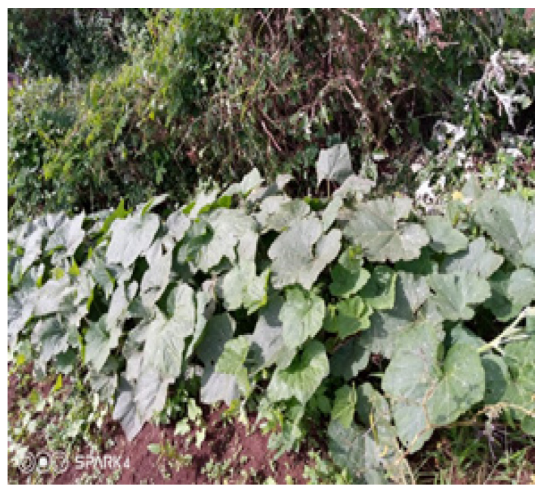

Common name: Pumpkin

Botanical name: Curcubita spp

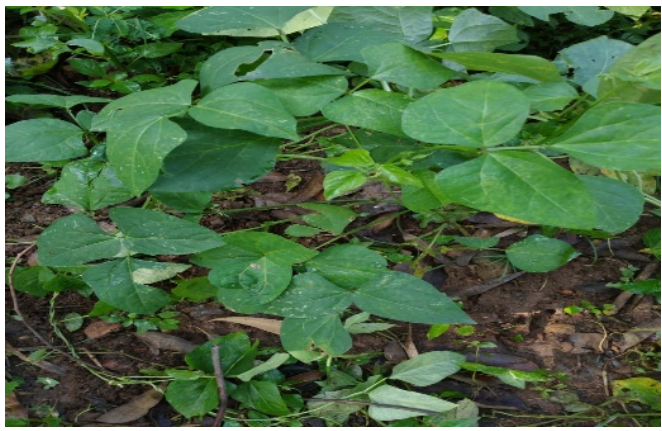

Common name: Cowpeas

Botanical name: Vigna unguiculata

\section{References}

[1] M. Abukutsa-Onyango (2007). The diversity of cultivated African leafy vegetables in three communities in Western Kenya. African Journal of Food, Agriculture and Nutrition Development, 7 (3 and 4):85-91

[2] M.O. Abukutsa-Onyango et al., (2006) Improved community land use for sustainable production and utilization of African indigenous vegetables in the Lake Victoria region. In: Proceedings of the fifth workshop on sustainable horticultural production in the Tropics 23rd26th Nov. 2005, Egerton University Njoro 167-179.

[3] A. B. Ayanwale et al., (2016). Analysis of household demand for underutilized indigenous vegetables. Int J Vegetable Sci 22(6):570-577

[4] P. K. Chelang'a et al., (2013). Analysis of urban consumers' willingness to pay a premium for frican Leafy Vegetables (ALVs) in Kenya: a case of Eldoret Town. Food Secur. 5, 591-595 http://dx.doi.org/ 10.1007/s12571-013-0273-9. 
[5] A. Faber M, Oelofse et al., (2010). African leafy vegetables consumed by households in the Limpopo and KwaZulu-Natal provinces in South Africa. S Afri J Clin Nutri 23(1):30-38

[6] O.E. Gido et al., (2016). Consumer's choice of retail outlets for African indigenous vegetables: empirical evidence among rural and urban households in Kenya. Cogent Food Agric 2(1):1-14.

[7] O. E. Gido et al., (2017). Consumer acceptance of leafy African indigenous vegetables: comparison between rural and urban dwellers. International Journal of Vegetable Science. doi.org/10.1080/ 19315260.2017.1293758.

[8] Government of Kenya, (2019). National Food Security and Nutrition Policy, Sessional paper, Government of Republic of Kenya, Nairobi.

[9] J. A. Hughes and J. D.H. Keatinge, (2013). The nourished millennium: how vegetables put global goals for healthy, balanced diets within reach. In: Holmer R, Linwattana G, Nath P, Keatinge JDH (eds) Proceedings of regional symposium on high value vegetables in Southeast Asia: production, supply and demand (SEAVEG 2012). AVRDC, Chiang Mai, Thailand.

[10] W. S. Jansen van Rensburg et al., (2007). African leafy vegetables in South Africa. Water South Africa 33:317-326.

[11] R. Kahane et al., (2013). Diversity for development: the role of opportunity crops and species. J. Agron. Sust. Dev. 33, 671-693.

[12] J.D.H. Keatinge et al., (2014). Projecting annual air temperature changes to 2025 and beyond: implications for vegetable production worldwide. J. Agric. Sci. Camb. 152, 38-57 http://dx.doi.org/ 10.1017/ S0021859612000913.

[13] G.M. Legwaila et al., (2011). Potential of traditional food plants in rural household food security in Botswana. Journal of Horticulture and Forestry,3 (6):171-177

[14] E. Lyatuu and L. Lebotse (eds), (2010). Marketing of indigenous leafy vegetables and how small scale farmers can improve their incomes. Agricultural Research Council, Dar es Salaam, Tanzania, (36)

[15] M. Lyimo et al., (2003). Identification and nutrient composition of indigenous vegetables of Tanzania. Plant Foods Hum. Nutr. 58, 85-92 http://dx.doi.org/10.1023/ A:1024044831196. PubMed

[16] P.M. Maundu (1997). The status of traditional vegetable utilization in Kenya. In: Proceedings of the IPGRI International workshop on Genetic Resources of Traditional Vegetables in Africa. Conservation and Use. ICRAF-HQ, Nairobi: IPGRI

[17] M. Maruyama, L. Wu L. and P. Tirdt (2014). Quantifying barriers impeding the diffusion of supermarkets in China: the role of shopping habits. J Retail Consum Serv 21:383-393

[18] M. Modi, A.T. Modi and Hendriks S (2006). Potential role for wild vegetables in household food security: a preliminary case study in Kwazulu-Natal, South Africa. Afr J Food Agric Nutr Dev 6:1-13

[19] E. Obel-lawson (2006). The efficacy of awareness campaigns by the African leafy vegetables project on nutrition behavior change among the Kenyan urban population: the case of Nairobi, M.S. Thesis, University of Nairobi, Kenya.

[20] N. K. Olembo, S.S. Fedha, and E.S. Ngaire (1995). Medical and Agricultural Plants of Ikolomani, Kakamega District, Kenya.

[21] C. M. Onyango et al., (2009). Feasibility of Commercial production of Amaranth Leaf vegetable by small scale farmers in Kenya. African Crop Science Conference Proceedings, Vol. 9. pp. $767-772$ 
[22] S. Singh et al., (2013). Indigenous vegetables for food and nutritional security in Andaman and Nicobar Islands, India. Int J Agric Food Sci Technol 4(5):503-512.

[23] I. H.J. Vorster et al., (2007). The importance of traditional leafy vegetables in South Africa. Afr J Food Agric Nutr Dev 7(4):1-13

[24] J. Waudo et al., (2007). Utilization and medical value of indigenous leafy vegetables consumed in urban and peri-urban Nairobi. Afr J Food Agric Nutr Dev 7(4):27-32 